\title{
MODERN PROCEDURES IN TECHNOLOGY OF CONSERVING LUCERNE BY ENSILING $^{1}$
}

\author{
B. Dinić, N. Đorđević , Jasmina Radović, Snežana Ignjatović
}

Abstract: Always actual issue of the technology of conserving lucerne and other legume species by ensiling is a result of the world's trend to use stable rations based on conserved food throughout the whole year for ruminants nutrition. Lucerne conserving by ensiling is more efficient solution compared to natural drying of forage because the procedure is less dependant on weather conditions. Furthermore, conserving by ensiling is much cheaper in comparison with artificial drying (dehydration).

A high buffer capacity of lucerne and low content of fermentable carbohydrates requires special procedures and supplements to be applied in order to obtain quality silage or haylage. The increasing demand of modern consumers today is to exclude from the application various chemical substances for lucerne conserving regardless of their high efficiency in preserving nutritive value of silage. In Europe chemical preservatives based on organic acids and their salts are still in use but with the trend of their restricting. On the contrary, the use of biological additives, which are less efficient but more easily applied, is more emphasized. These additives do not leave any residues either in silage or products obtained by animals fed such silage. For the last decade of the XX century the application of biological additives based on homofermentative lactic acid bacteria (LAB), with or without enzymes which additionally increase utilization of potential nutritive value of lucerne silages is being characteristical. Now, experiments are made on the III generation of biological additives, which besides homofermentative, contain also heterofermentative LAB. The products of such inoculants contribute to increasing aerobic stability of silages, and are now used for all kinds of silages. Besides using mentioned additives, modern technology of lucerne ensiling is based on maximal mechanization of a whole process of ensiling as well as preparing silage in the form of big bales and tubes what can be performed without permanently built silo-facilities.

Key words: lucerne, silage, preservatives, inoculants, aerobic stability, big bales.

\section{Introduction}

Economical production of ruminants milk and meat is based on the use both of maximum quantities of forage feeds and by-products of arable farming, vegetable crops farming and feed industry. Forage is certainly the cheapest food but its usage is restricted by the length of vegetation period and weather conditions. A great variability of a chemical composition of such a produced food in so short a period adversely affect the quality and quantity of milk, as well as an overall physiological processes in ruminants. By conserving forages by drying or ensiling a physiological processes in plants are being terminated and in this way further decrease of nutritive value in given moment is being stopped. In the countries with highly developed livestock production the concept of using conserved forage feeds in the nutrition of ruminants throughout a whole year is more in use. This concept provides maximally stable rations and therefore a stable milk production as well.

Hay and silage are major forms of conserved forage feeds. The fact that the quality of hay is influenced by weather conditions resulted in its limited preparation and utilization and replacing it by silage. First of all, the hay is more expensive food, although minimum quantities are needed for a normal functioning of a ruminants complex digestive system. In many countries there is a trend of preparing and utilization of greater quantities of silage instead of hay (Wilkinson and Toivonen, 2003; Table 1). Grass and maize silages are predominant, while the silages of legumes and different by-products of arable farming, crop farming and food industry are used in lesser degree.

\footnotetext{
1 Review paper supported by the Ministry of Science and Environment Protection, Project no. TR6872B - Revijalni rad je finansiran od strane Ministarstva za nauku i zaštitu životne sredine Projektom broj: TR6872B

2 Dr Bora Dinić, research counselor, mr Jasmina Radović research associate, mr Snežana Ignjatović, research associate, Institut SERBIA, Centar for forage crops, Trg Kosturnice 50, 37000 Kruševac;

Doc. dr Nenad Djorđević, Faculty of Agriculture, Nemanjina 6, 11081 Zemun.
} 
Table 1. Estimated production of silage and hay in different countries (Wilkinson and Toivonen, 2003)

\begin{tabular}{|c|c|c|c|c|}
\hline \multirow[t]{3}{*}{ Country } & \multicolumn{4}{|c|}{$\begin{array}{c}\text { Estimated production } \\
\text { Milion tonnes dry matter }\end{array}$} \\
\hline & \multirow[t]{2}{*}{ Hay } & \multicolumn{3}{|c|}{$\begin{array}{l}\text { Silage } \\
\end{array}$} \\
\hline & & Grass & Maize & Other \\
\hline Australia & 4,5 & 0,9 & 0,3 & 0,024 \\
\hline Austria & 1,9 & 1,6 & 1,2 & 0,2 \\
\hline Canada & 45,0 & - & 2,8 & 4,8 \\
\hline Denmark & 0,07 & 0,8 & 0,6 & 0,8 \\
\hline Finland & 0,6 & 1,8 & - & 0,02 \\
\hline France & 22,5 & 6,1 & 16,8 & 5,3 \\
\hline Germany & 2,0 & 8,6 & 14,6 & 3,2 \\
\hline Greece & 1,3 & - & 0,3 & - \\
\hline Italy & 15,1 & 0,2 & 6,9 & 0,4 \\
\hline Japan & 1,5 & 2,2 & 1,1 & 0,07 \\
\hline New Zealand & 0,4 & 0,6 & 0,3 & 0,02 \\
\hline Norwey & 0,08 & 2,3 & - & 0,1 \\
\hline Poland & 8,6 & 2,1 & 2,2 & 2,6 \\
\hline SCG & 3,1 & 0,01 & 0,1 & 0,3 \\
\hline Sweden & 0,4 & 3,6 & 0,03 & 0,02 \\
\hline The Netherlands & 0,3 & 4,3 & 2,9 & 0,07 \\
\hline United Kingdom & 2,5 & 9,4 & 1,1 & 0,4 \\
\hline USA & 138 & 1,7 & 32,4 & 9,0 \\
\hline
\end{tabular}

The suitability and importance of lucerne for ensiling

Lucerne and maize are main forages in our country. They differ substantially in their chemical composition and nutritive value, but for that reason they supplement each other perfectly in ruminants rations. A high buffer capacity of lucerne (a consequence of high percent of protein and calcium) and small content of fermentable carbohydrates are the main factors for lower use of ensiling this species (Dinić et al., 1998). For that reason since the thirties of the XX century, many experiments had been conducted with the aim to find out the most successful technique of lucerne conserving by ensiling (Đorđević and Dinić, 2003). During the development of ensiling technology the results of many experiments have been either successfully applied in practice (chemical preservatives based on organic acids, carbohydrate additives, wilting, biological preparations) or they have proved impractical (mineral acids) (Dinić et al., 2004). Today in Europe, but also in the rest of the world, the use of biological preparations and organic acids is being highlightened. A major aim of modern technologies is to obtain as best quality silage as possible along with its maximum aerobic stability and nutritive value.

\section{Wilting}

Wilting, or a short-term drying, is certainly the cheapest solution for successful ensiling of legumes, grasses and grass-legumes mixtures. An efficient conserving of wilted plants is explained by an outstanding ability of LAB to be active in the environment with increased osmotic pressure so that a majority of other anerobic microorganisms cannot compete with them. Such a procedure, based on the experiences of the Italian Samarani dating from the middle of the last century, is regularly applied nowadays when ensiling the plants with delicate stem. A positive experiences of using this technology have also been proved by our experiments (Dinić, 1990; Đorđević, 1995) and they are widely used in practice on our farms (Đorđević and Dinić, 2003). Wilting is also important because of its limiting influence on a degree of proteolysis in lucerne silages (Đorđević et al., 2004). However, a possibility of wilting depends on weather conditions and cannot be always performed. Moreover, wilting requires an additional engagement of mechanization and men labour for harvesting and handling, at which the contamination by soil, sand and other substances is highly probable. 
Mixing with forages that are easily ensilaged and adding of carbohydrate feeds

Mixing of lucerne with forages that are easily ensilaged themselves is usually in early autumn, in the time of the last cut of lucerne, as well as in the time of the silage maize or sorghum from the main or subsequent sowing (Dinić et al., 1988; 1995). Besides, it is possible to mix lucerne with small grains in which case the II cut of lucerne is most used (Đorđević and Dinić, 2003). In such combinations the grains provide a necessary content of carbohydrates while legumes enrich silage by protein. According to Koljajić et al. (1998) a whole maize silage contains $64,40 \mathrm{~g} / \mathrm{kg} \mathrm{DM}$ crude protein, while the silage made of whole maize and lucerne (green mass ratio 50:50\%) contains $124,35 \mathrm{~g} / \mathrm{kg}$ DM crude protein. Lucerne maximum ratio in combined silages with maize is $50: 50 \%$ (Dinic et al., 1988). From a practical point of view, the ratio of maize and lucerne in mixtures being ensiled depends, in the first place, on available quantities of lucerne.

In order to provide needed carbohydrates content for lactic acid fermentation the addition of carbohydrate feeds such as maize grits $(5-10 \%)$, molasses $(1 \%)$, dry sugarbeet cuts $(5-10 \%)$ and other (Koljajić et al., 1997) is applied in practice.

\section{Use of chemical preservatives}

Chemical conserving of plants is based on the inhibition of vegetative enzymes by lowering $\mathrm{pH}$ below 4,5. The first trials in which chemical preservatives in ensiling were used started in the late XIX century, so until now more than 1000 different compounds have been examined. However, nowadays, only a small number of these acids is used, and mostly organic acids (formic and propionic) and their salts, while sulphuric, hydrochloric and phosphoric acids are hardly ever used. One of the main reasons for that is the effort to produce most natural and healthy human and animal food as possible. In our country in the last few decades there was a lot of trials with formic acid in which its effects were compared with chemical preservatives (mineral acids and their salts), carbohydrate supplements or bacterial inoculants (Dinić et al., 1994-a,b; 1996; 1997; Đorđević et al., 2003-a). Although very good results were obtained these supplements are not used in our country because they are very expensive.

Today in Europe there are various commercial preparations in form of mixtures of two organic acids, acid and salt or several salts (Pflaum, 2003; Lattemae et al., 2003). In such mixtures there occurs mutual supplementation of the action of singular components since neither of them has a universal action. Thus for example, formic acid has a bactericidal activity while propionic acid has a fungicidal activity, so by their mixing in suitable proportion more efficient conservation is achieved. A composition of such mixtures is most often unknown and marked as a producer's secret.

\section{The use of biological additive}

An advantage of biological additives over chemical preservatives is primarily in the fact that they do not leave any residues and do not affect adversely the health of animals and the quality of their products. For that reason they are increasingly pushing out chemical preservatives, regardless of their smaller efficiency. In our experiments we have confirmed a positive effects of the use of biological additives (Đordević, 1995; Đorđević et al., 2000), which are used in practice at our big farms (Đorđević and Dinić, 2003). The greatest effects of bacterial inoculation are demonstrated in feeds difficult to ensilage, legumes in the first place, because by the use of homofermentative cultures a present soluble carbohydrates which are on the very verge of sugar minimum, are most efficiently utilized. Besides, by the use of bacterial inoculants at the very onset of fermentation the domination of lactic acid bacteria is obtained as regards natural microflora.

First made preparations based on lactic-acid bacteria contained homofermentative microorganisms, in monoculture or as a combination of more species. In majority of trials it has been proved that the combinations of different bacteria are more flexible regarding the choice of nutritive substances, temperature interval and other conditions, they supplement each other in different aspects of their activity, in comparison with monocultures. Modern biological preparations contain Lactobacillus plantarum and other Lactobacillus species, in combination with Enterococcus, Lactococcus and Pediococcus species. In the next phase of the development of this technology there was a trend of combining bacteria of lactic acid fermentation with cellulytic enzymes. By the use of such preparations the lactic acid fermentation of homofermentative type is not only intensified but different fraction of fibre are being degraded as well and simultaneously the content of fermentable carbohydrates is being increased. Ultimate effect of such additives is to improve the silage 
quality (Avasi et al., 1999) and digestibility. Recently a great attention has been paid to the possibilities of increasing aerobic stability of silages, primarily maize, and some other plant species, since lactic acid as a main product of sugar fermentation in silage represents strong bactericidal but weak fungicidal device. Acetic, butyric and propionic acid have displayed a distinct fungicidal activity, so that small quantities of these acids, in maize silages, but also in other plants silages, are even desirable (Table 2). In more than one trial it was confirmed that inoculation with Lactobacillus buchneri improves aerobic stability of silages of different plants, namely grass silages (Honig, 1990), maize (Ranjit and Kung, 2000) and lucerne (Bodarsky et al., 2003). In order to increase silage aerobic stability the investigations were also made with propionic acid bacteria in which decreased losses and improved fermentative processes (Gallo et al., 2003) were obtained.

Table 2. Biochemical changes in lucerne silages (Avasi et al. 1999)

\begin{tabular}{|l|c|c|c|}
\hline Parametres & Control & Sil-All & Feed Tech \\
\hline $\mathrm{PH}$ & 5,12 & $4,75^{\bullet \bullet}$ & $4,82^{\bullet \bullet}$ \\
\hline acids, \% & & & $2,21^{\bullet \bullet}$ \\
\hline lactic & 1,86 & $2,76^{\bullet \bullet}$ & $0,81^{\bullet \bullet}$ \\
\hline acetic & 0,74 & $0,98^{\bullet}$ & 0,0120 \\
\hline butyric & 0,015 & 0,015 & 0,00 \\
\hline butyric & $0,035^{\bullet}$ & 0,00 & 0,015 \\
\hline propionic & $0,065^{\bullet}$ & 0,015 & 130,7 \\
\hline $\mathrm{NH}_{3}-\mathrm{N}, \mathrm{mg}^{\bullet}$ & $157,0^{\bullet}$ & 150,2 & \\
\hline
\end{tabular}

Sil-All=Streptococcus faecium, Pediococcus acidilactici, Lactobacillus plantarum+enzymes cellulase;

Feedtech $=$ Pediococcus acidilactici+Lactobacillus plantarum, $2,5 \times 10^{8} \mathrm{cell} / \mathrm{g}$.

$* \mathrm{p}<0,05 ; * * \mathrm{p}<0,01$

In a perspective of further increasing the effects of the use of inoculants is a selection and genetic manipulation with lactic acid bacteria. A future aim of selection is to choose most efficient strains of bacteria in accordance with the type and chemical composition of forage as well as wheather conditions (Merry et al., 1997). There are even attempts to increase the efficiency of Lactobacillus species by a gene manipulation (Fitzsimons et al., 1994).

The importance of modern mechanization for lucerne ensiling

One of the modern procedures in the technology of ensiling is preparing the silage in bales, wrapped by foils. In USA today the most economical way of making silages is in the form of tubes. Such a procedure requires no built silo-facilities while the prepared tubes can be kept under the eaves, or in open field, until the moment of use. Wilted plant material made into bales should contain as less humidity as possible since the pressing is made by the press, and could be additionally treated by chemical substances or inoculants with the aim of obtaining best possible quality. A great advantage of silage made in bales is in its manipulation or handling, and forage conserved in such a way is suitable for market (Dinić and Đorđević, 2005). The results of some early experiments indicate that in silage bales lucerne silage attain almost the same quality as by ensiling in conventional silo-facilities (Jatkauskas and Vrotniakiene, 2003; table 3)

Table 3. Chemical composition of silages ensiled in different methods, feed intake and animal performance in the experimental period (Jatkauskas and Vrotniakiene, 2003)

\begin{tabular}{|c|c|c|c|c|}
\hline Parametres & Silage in trench & Silage in big bales & SEM & $\mathrm{P}$ \\
\hline $\mathrm{pH}$ & 4,52 & 4,65 & 0,1 & NS \\
\hline Lactic acid & 22,1 & 21,7 & 0,9 & NS \\
\hline Acetic acid & 17,6 & 14,5 & 1,2 & NS \\
\hline Butyric acid & 0,01 & 0,00 & 0,0 & $\mathrm{NS}$ \\
\hline $\mathrm{NH}_{3}-\mathrm{N}, \mathrm{g} / \mathrm{kg} \mathrm{N}$ & 50,8 & 45,6 & 2,4 & $\mathrm{NS}$ \\
\hline $\mathrm{ME}, \mathrm{MJ} / \mathrm{kg} \mathrm{DM}$ & 8,89 & 8,94 & 0,9 & $\mathrm{NS}$ \\
\hline NE intake, MJ/day & 88,91 & 98,82 & - & - \\
\hline Silage intake, $\mathrm{kg}$ DM & 7,19 & 7,26 & - & - \\
\hline Initial live weight, $\mathrm{kg}$ & $356,33 \pm 18,64$ & $354,60 \pm 19,17$ & - & - \\
\hline Total live weight, $\mathrm{kg}$ & $159,44 \pm 14,13$ & $163,50 \pm 4,35$ & - & - \\
\hline Average live weight gain, $\mathrm{kg} /$ day & $1,115 \pm 0,09$ & $1,143 \pm 0,03$ & - & - \\
\hline
\end{tabular}


Making concepts for rations based on lucerne silages

Silages are highly variable in nutritive value, what depends, in the first place, on the original material. For example, whole maize silage is high in energy, but low in protein and minerals, while the silage and hay of lucerne is high in protein and calcium but low in energy. A ration which contains only one kind of silage should be balanced by including corresponding feeds which are an adequate source of deficient nutrient or by combining the silages of different plant species (Đorđević et al., 2002; 2003-b). The effect of such rations on milk production was investigated in detail by Brito and Broderick (2004). These authors in the trial with Holstein cows, had used four types of rations, characterized by different dry matter proportions of lucerne and maize silage (50:0;37:13;23:27 and 10:40). The most favourable for production were rations with the proportion of lucerne and maize silage of 37:13 and 23:27. In the trial with maximum dose of maize silage they have obtained poorer production by $3,5 \%$ fat corrected milk and milk fat, while in treatments with lucerne silage a significantly less milk protein was produced. It is another proof that for the adequate production of milk fat a certain level of efficient fibres is necessary as well (Grubić et al., 1999). On the other hand, because of its high solubility and degradation, protein of legumes are less used in milk production compared with protein which are in great part digested and uptaken only at the level of small intestine. These processes are now explained in detail by contemporary standards for the nutrition of cows $(N R C$, 2001). On the basis of results obtained, Brito and Broderick (2004) do not recommend the use of rations based on one kind of silage only.

In our production conditions, in rations for high productive cows together are used different quantities of silages made of mixtures of annual legumes and corn, lucerne silage, whole maize silages and silages of maize wet grain. In these rations a minimal quantities of hay are included taking into consideration its high price (Adamović et al., 2001)

\title{
Conclusion
}

Modern trends in technology of ensiling lucerne are based on the latest scientific and technical achievements. Different procedures were first studied in experiments and then introduced into practice. In this respect, a great number of trials were conducted in our country in accordance with specific conditions and such acquired knowledge was transferred into actual recommendations which are used in our practice at a large scale. The aim of application of modern procedures of ensiling is to obtain silages made of different raw-material of the highest quality, with optimal satisfying of many nutritive needs, but also with obtaining maximally healthy products of animal origin for human consumption.

\section{SAVREMENI POSTUPCI U TEHNOLOGIJI KONZERVISANJA LUCERKE SILIRANJEM}

\author{
B. Dinić, N. Đorđević , Jasmina Radović, Snežana Ignjatović
}

$$
\text { Rezime }
$$

Savremeni trendovi u tehnologiji siliranja lucerke baziraju se na najnovijim naučnim i tehničkim dostignućima. Različiti postupci su najpre ispitani u eksperimentima, a zatim uvedeni u praksu. U tom pogledu vršena su brojna domaća istraživanja u skladu sa specifičnim uslovima, a tako stečena znanja su pretočena u konkretne preporuke, koje se uveliko primenjuju u našoj praksi. Cilj korišćenja savremenih postupaka siliranja jeste dobijanje silaža od različitih sirovina najvišeg kvaliteta, uz optimalno zadovoljenje brojnih nutritivnih zahteva, ali i dobijanje maksimalno ispravnih proizvoda animalnog porekla za ljudsku upotrebu. 


\section{References}

1. ADAMOVIĆ M. (2001): Proizvodnja silaže i senaže. Priručnik. Portal-Beograd.

2. AVASI Z., SZÜHCSNE J., MARKY-ZAJNE I.K. (1999): Ensilage of lucerne by biological preservatives. 9. Medzinarodne sympozium "Konzervovanie objemovych krmiv" - Nitra, 6.-8. september 1999. Zbornik referatov, 142-143.

3. BODARSKY R., STEMPNIEWICZ R., KRZYWIECKI S., KRZYSKO-LUPICKA T., SLUPCZYNSKA M. (2003): Quality, Microbiologocal status and aerobic stability of wilted grass-alfalfa silages made with different (chemical or biological) additives. $11^{\text {th }}$ International symposium "Forage conservation. $9^{\text {th }}-11^{\text {th }}$ September 2003, Nitra, Slovak Republic. 114-115.

4. BRITO A. F., BRODERICK G. A. (2004): Effects of different dietary rations of alfalfa and corn silage on milk production of lactating dairy cows. U.S. Dairy forage research center. 2003 research summary. September, 2004. pp. 74-77.

5. DINIĆ B., STOŠIC M., KOLJAJIĆ V. (1988): Uticaj različitog odnosa lucerke i kukuruzne biljke na kvalitet silaže. VI jugoslovenski simpozijum o krmnom bilju. Poljoprivredni institut - Osijek, 2224.06.1988. Zbornik radova, 525-534.

6. DINIĆ B. (1990): Uticaj provenjavanja silo-krme crvene deteline i konzervansa na kvalitet silaže. Arhiv za poljoprivredne nauke. 51, 183: 235-244.

7. DINIĆ B., STOŠIĆ M., KOLJAJIĆ V., RADOVIĆ J. (1994-a): Possibilities of alfalfa conservation with formic acid at different dry matter levels. Review of research work at faculty of agriculture. 39, 2: 25-34.

8. DINIĆ B., KOLJAJIĆ V., LAZAREVIĆ D., RADOVIĆ J. (1994-b): Effects of cut, dry matter level and formic acid on dynamics of biochemical changes in alfalfa silage. Journal of scientific agricultural research. 198, 56: 77-87.

9. DINIĆ B., KOLJAJIĆ V., STOŠIĆ M., IGNJATOVIĆ S., LAZAREVIĆ D. (1995): Examinations on the possibility of alfalfa ensiling. $7^{\text {th }}$ International symposium Forage conservations. September $18^{\text {th }}-20^{\text {th }}$, Nitra, Sovak Republic. 105-109.

10. DINIĆ B., KOLJAJIĆ V., STOŠIĆ M., IGNJATOVIĆ S., LAZAREVIĆ D. (1996): Korišćenje ugljenohidratnih hraniva i mravlje kiseline za konzervisanje lucerke. VIII jugoslovenski simpozijum o krmnom bilju. Zbornik radova, 26: 491 - 497.

11. DINIĆ B., STOŠIĆ M., NEGOVANOVIĆ D., IGNJATOVIĆ S., TOMIĆ Z., JEVTIĆ G. (1997): Influence of plant growth phase, dry mass level and chemical conservators on lucerne ensilage. Proceedings of the 8th International symposium Forage Conservation. Research Institute of Animal Nutrition, Ltd. Pohorelice, 29.09-01.10.1997. 122-123.

12. DINIĆ B., KOLJAJIĆ V., ĐORĐEVIĆ N., LAZAREVIĆ D., TERZIĆ D. (1998): Pogodnost krmnih biljaka za siliranje. Savremena Poljoprivreda. 1-2: 154-162.

13. DINIĆ B., ĐORĐEVIĆ N., IGNJATOVIĆ S., SOKOLOVIĆ D. (2004): Savremeni trendovi u tehnologiji siliranja. X simpozijum o krmnom bilju Srbije i Crne Gore sa međunarodnim učešćem. Acta Agriculturae Serbica. 9, 17: 553-564.

14. DINIĆ B., ĐORĐEVIĆ N. (2005): Pripremanje i korišćenje silaže (Priručnik). Vizartis - Beograd.

15. ĐORĐEVIĆ N. (1995): Effects of conserving lucerne with different dry matter content. Review of research work at the faculty of agriculture. 40, 1: 93-107.

16. ĐORĐEVIĆ N., GRUBIĆ G., ADAMOVIĆ M. (2000): Influence of wilting, inoculant and carbohydrate additives on lucerne silage quality. $51^{\text {th }}$ Annual Meeting of EAAP. The Hague, 21-24 August 2000. Abstract no. 168 .

17. ĐORĐEVIĆ N., KOLJAJIĆ V., GRUBIĆ G., ADAMOVIĆ M., GLAMOČIĆ D. (2002): Silaža lucerke $\mathrm{u}$ ishrani krava. XVI savetovanje agronoma, veterinara i tehnologa. INI PKB Agroekonomik, Beograd. Zbornik naučnih radova, 8, 1: 329-340.

18. ĐORĐEVIĆ N., DINIĆ B. (2003): Siliranje leguminoza (monografija). Vizartis - Beograd.

19. ĐORĐEVIĆ N., GRUBIĆ G., ADAMOVIĆ DINIĆ B., LAZAREVIĆ D. (2003-a): Intensity of biochemical changes in lucerne silages with addition of zeolite and formic acid. $11^{\text {th }}$ International symposium "Forage conservation. $9^{\text {th }}-11^{\text {th }}$ September 2003, Nitra, Slovak Republic. Str.. 132-133.

20. ĐORĐEVIĆ N., DINIĆ B., GRUBIĆ G., ALEKSIĆ D., GLAMOČIĆ D. (2003-b) Uticaj korišćenja različitih vrsta silaža na produkciju i hemijski sastav mleka. Mlekarstvo, 24: 842-849. 
21. ĐORĐEVIĆ N., DINIĆ B., GRUBIĆ G., KOLJAJIĆ V. DUJIĆ D. (2004): Kontrola proteolitičkih procesa u siliranoj hrani. X simpozijum o krmnom bilju Srbije i Crne Gore sa međunarodnim učešćem.Acta Agriculturae Serbica. 9, 17: 565-572.

22. FITZSIMONS A., HOLS P., JORE J., LEER R.J., O'KONNELL M., DELCOUR J. (1994): Development of an amylolytic Lactobacillus plantarum silage strain expressing the Lactobacillus amylovorus alpha-amylage gene. Applied \& Environmental Microbiology. 60 (10) : 3529-3535.

23. GALLO M., RAJČAKOVA LJUBICA, MLYNAR R. (2003): Effect of application biological additive on fermentation quality of red clover silage. $11^{\text {th }}$ International symposium "Forage conservation. $9^{\text {th }}-11^{\text {th }}$ September 2003, Nitra, Slovak Republic. 96-97.

24. GRUBIĆ G., ĐORĐEVIĆ N., RADIVOJEVIĆ M. (1999): Fizičke osobine vlakana u obrocima za krave. Arhiv za poljoprivredne nauke. Vol. 60., $\mathrm{N}^{0} 210,1-2:$ 61-72.

25. HONIG H. (1990): Evaluation of aerobic stability. In Proceedings of the EUROBAC Conference, Uppsala, 1986 (Eds. S. Lindgren and K. Lunden Petterson), Grovfoder, Grass and Forage Reports, Special issue, 3, 1990, 76-82, Swedish University of Agricultural Sciences.

26. JATKAUSKAS J., VROTNIAKIENE V. (2003): Fermentation characteristic and nutritive value of red clover-grass made in big bales and trench. $11^{\text {th }}$ International symposium "Forage conservation. $9^{\text {th }}-11^{\text {th }}$ September 2003, Nitra, Slovak Republic. 90-91.

27. KOLJAJIĆ V., ĐORĐEVIĆ N., GRUBIĆ G., JOVANOVIĆ R., PAVLIČEVIĆ A., JOKIĆ Ž., DINIĆ B. (1997): Kvalitet silaža spremljenih od leguminoza u zavisnosti od korišćenih postupaka i dodataka. Simpozijum „Naučna dostignuća u stočarstvu '97'. Subotica, 21.-25. april. Zbornik radova, 203-219.

28. KOLJAJIĆ V., ĐORĐEVIĆ N., GRUBIĆ G. (1998): Effects of inoculants on ensiling of maize plant and alfalfa at different rations. Review of Research Work at the Faculty of Agriculture. 43, 2: 101-110.

29. LATEMAE P., LAATS A., TAMM U. (2003): Effect of using additives, herbage wilting and different crops on quality of big bale silage. $11^{\text {th }}$ International symposium "Forage conservation. $9^{\text {th }}-11^{\text {th }}$ September 2003, Nitra, Slovak Republic. 140-141.

30. MERRY R.J., LOWES K.F., WINTERS A.L. (1997): Current and future approaches to biocontrol in silage. Proceedings of the 8th International symposium Forage coservation. Research Institute of Animal Nutrition, Ltd. Pohorelice. 17-27.

31. NATIONAL RESEARCH COUNSIL (2001): Nutrient Requirements of Dairy Cattle. 7th rev. ed., National Academy Press, Washington, D.C.

32. PFLAUM J. (2003): The influence of additives and storage time on the aerobic stability of maize silage. $11^{\text {th }}$ International symposium "Forage conservation. $9^{\text {th }}-11^{\text {th }}$ September 2003 , Nitra, Slovak Republic. 106-107.

33. RANJIT N.K., KUNG L. (2000): The effect of Lactobacillus buchnery, Lactobacillus plantarum, or chemical preservative on the fermentation and aerobic stability of corn silage. Journal of Dairy Science. 83: 526-535.

34. WILKINSON, J.M., TOIVONEN, M.I. (2003): World silage-a survey of forage conservation around the world. School of Biology, Universiti of Leeds, Leeds, LS2 9JT, United Kingdom. 